\title{
Reducing the Tax Burden in Ukraine: Changing Priorities
}

\author{
Tetiana Paientko ${ }^{1}$, Valeriy Oparin ${ }^{2}$
}

Submitted: 8.10.19. Accepted: 6.07.20

\section{Abstract}

Purpose: To determine the impact of changes in tax burden in Ukraine on the country's economic freedom.

Methodology: The study applies qualitative methods for historical analysis, periodization of reforms, and classification of their key priorities and influences. Quantitative methods are applied to compare tax burden (tax-to-GDP ratio) in Ukraine and OECD countries. The overall success and failure of tax reforms was measured by the index of economic freedom, including its component, the index of tax burden (fiscal freedom). The first hypothesis suggested that a reduction in tax burden positively impacted the level of economic freedom in Ukraine; the second hypothesis stated that a reduction in tax burden positively affected the fiscal freedom of Ukraine. Regressions in average tax burden and the index of economic freedom, including the index of tax burden, were built in R software.

Findings: Regression analysis did not confirm the first hypothesis. The second hypothesis was confirmed. Reduced tax burden does not affect the level of economic freedom of Ukraine. This is explained by the slow progress of institutional reforms in Ukraine. The reduction of tax burden has a significant positive impact on the level of fiscal freedom.

Practical Implications: The results obtained have practical relevance for the elaboration of fiscal policies in developing countries, in accordance with the country's economic and political development priorities.

Research Limitations/Implications: Future research will include a more in-depth comparative analysis of tax reforms in Ukraine, focusing on the key taxes.

Keywords: tax, tax reform, tax-to-GDP ratio, tax burden, index of economic freedom.

JEL: H20, H21, E62

\footnotetext{
1 Kyiv National Economic University n.a. Vadym Hetman, Peremohy Ave, 54/1, Kyiv, Ukraine, 03057, e-mail: tpayentko@kneu.edu.ua, https:// orcid.org/0000-0002-2962-308X

2 Kyiv National Economic University n.a. Vadym Hetman, Peremohy Ave, 54/1, Kyiv, Ukraine, 03057, e-mail: oparin _ vm@ukr.net.
} 


\section{Introduction}

After gaining independence, Ukraine launched a series of tax reforms. An important part of these reforms was the reduction of tax burden, which was initially seen as a way to enhance economic growth and, at later stages, to curb the shadow economy present in the country. The reforms involved changes in the number of taxes and structure of the tax system, base, rates, administration, and other elements.

In Ukraine, scarcely a year has passed without some form of change in the tax law or other related fields. Eventually, this lack of stability triggered a public discussion about the need to freeze tax reform since it was hard for businesses to keep up with the changes. Let us note that although such a measure was considered to be necessary and even urgent, it was never implemented. In light of the above, questions arise as to how adequate the goals and priorities of the Ukrainian tax reforms were, whether they were really needed, whose interests they served, how efficient they were, and what determined the change of priorities during reforms.

This article aims to determine the impact of changes in tax burden in Ukraine on the economic freedom of the country. We propose the following hypotheses:

H1: The reduced tax burden in Ukraine has a positive impact on the level of economic freedom of Ukraine.

H2: The reduced tax burden has a positive effect on the level of fiscal freedom of Ukraine.

Quantitative and qualitative methods were used to test the hypotheses. Qualitative methods are needed to assess institutional changes in taxation. Quantitative methods were used to obtain quantitative indicators of tested variables impact on the result.

The article is structured in the following way. The introduction is followed by a literature review on tax reform practices in OECD countries and in Ukraine. In the third section, we describe our research methodology and hypotheses. The fourth section focuses on the evolution of taxation in Ukraine. The fifth section contains the results of the research. The last section contains conclusions and prospects for further research. 


\section{Literature Review}

The evolution of tax law can be considered from a variety of different approaches and angles. The choice of approaches largely depends on the differences in the development of national economies and, therefore, in the specific problems in the tax sphere that certain countries need to address.

The fundamental contribution to the study of links between taxation and country development was made by Tanzi (1997), who defines how budgetary policy and economic aggregates interact, and how economic indicators respond to fiscal policy.

Western economists mostly seek to identify the weaknesses in current taxation systems and search for ways of solving existing problems. Let us note that the majority of tax reforms in developed countries are aimed at minimizing the negative impact of taxation on key macro-indicators (see Gale and Samwick, 2014). This study shows that reduced income tax burden can increase the productive capacity of businesses, which means that fewer government subsidies will be required. The connection between taxation and economic growth is discussed by McBride (2012). Joseph et al. (2015) highlight the connection between policy choices regarding state revenues, and expenditures and the impact of changes in taxation on economic growth, taking time lag into consideration. Barrios et al. (2012) research the impact of taxation on decision-making in international firms concerning the location of their foreign subsidiaries. Noteworthy, problems of profit shifting to low-tax jurisdictions and the resulting tax base erosion are widely discussed by international researchers, who describe the possible reforms of tax systems that would allow states to tackle these problems more effectively. Another related question concerns the influence of taxation on inequality and the tax reforms needed to reduce inequality and its associated risks. For example, Agrawal and Foremny (2018) analyze how tax rates influence the choices of location made by high-income taxpayers. A similar question is raised in the study by Schmidheiny and Slotwinski (2018). The impact of tax reforms on the international mobility of investors is considered in the study of Akcigit, Baslandze, and Stantcheva (2016). Guvenen et al. (2017) research the phenomenon of tax base erosion caused by offshore profit shifting. Another question that attracts much scholarly attention is the impact of tax reforms on economic growth (Barro et al., 2017; Furman and Jason, 2016) and macro-economic equilibrium (Gale and Samwick, 2014).

The goals pursued by reformers in developed countries are often similar, although there may be different reasons for initiating these reforms, such as the wish to maintain the macro-economic equilibrium when dealing with political pressures or the 
search for optimal taxation mechanisms to satisfy state and public fiscal needs. We should keep in mind that in developed economies, reforms are implemented in a transparent environment with low corruption levels and high degrees of government accountability.

The latest publications focusing on Ukrainian reforms focus on specific aspects of these reforms. Some studies consider the problem of taxation in the light of Ukraine's integration with the European Union; for example, Hrechko (2014), Nohinova (2014), and Ilyashenko (2013). Another group of studies considers the anti-crisis aspect of tax reforms: Melnik and Koschuk (2014), Turianskyi (2014). In comparison, Borzenkova (2015), Paientko and Proskura (2016), Paientko and Oparin (2017) investigate the outcomes of the reforms.

Although there is a vast amount of research literature on various aspects of tax reform, little attention has been given to the dominant factors that determined the course of the evolution of tax law in Ukraine. For example, tax reform in Ukraine is impeded by the high level of corruption, low information transparency, and the lack of government accountability (Fedosov and Paientko, 2017). These factors create resistance among taxpayers and curb the reforms' impact on the country's economic performance. Therefore, the results of the evolution of tax legislation in Ukraine are contradictory.

\section{Methodology}

The theoretical part of our study employs the historical and system methods. The historical method is applied to propose a periodization of tax reforms in Ukraine. The system method was used to describe the structure of changes in respective tax systems at specific stages; together with the inference method, it also helped identify factors and priorities of the tax reforms.

In the empirical part of the study, tax burden in Ukraine and their OECD counterparts are compared, and the impact of the tax reform on Ukraine's progress in the ranking of economic freedom is evaluated. The calculations were made with the help of R software. The databases for calculations were downloaded from the OECD (2019) and World Bank (2019) official websites.

The first stage of the study conducted a statistical analysis of tax burden in OECD countries. The main mission of the OECD is to contribute to the development of the world economy, promote the economic growth of member countries, and increase 
their contribution to global economic growth and development, along with the development of other countries outside of the organization. Thus, we may assume that tax systems of OECD member countries are constructed in a way to ensure the balanced development of economies. Due to the lack of data for Australia (no data for 2017) and Japan (no data for 2017-2018), those countries were not included in the sample. The sample covers the period from 1995 to 2018.

At the second stage, we constructed regressions of the mean tax burden (including social security contributions) and the index of economic freedom (including the index of fiscal freedom: tax burden). Tax burden (tax-to-GDP ratio) was used as an independent variable since tax reforms in Ukraine prioritized its reduction.

In order to evaluate outcomes of tax reforms and conclude about their success or failure, we should first examine the general state of Ukraine's economy. The tax climate shapes many indicators, including the dynamics of business development, investment activity, and rates of economic growth. It is practically impossible to comprehensively analyze the impact of tax law evolution within one study. At the same time, the analysis of only one factor is not enough to gain a full and accurate picture. Therefore, we selected an aggregate indicator for the purpose of research: the index of economic freedom. According to Berggren (2003), the index of economic freedom "enables researchers to carry out statistical analyses of the importance of economic freedom." Many researchers see the index of economic freedom as a measure of economic development, for example, Carlsson and Lundström (2002), Doucouliagos and Ulubasoglu (2006). Scholars also study the relationship between economic growth and taxation, for instance, Egger and Winner (2004) and Furman (2016). Therefore, the indices of economic and fiscal freedom can be indicators that characterize the results of changes in tax legislation.

The index of economic freedom and the index of fiscal freedom (tax burden) were chosen as dependent variables. The index of economic freedom is an integral indicator characterizing the level of economic freedom for business development in any given country. To measure the level of economic freedom in a country, we should examine not only certain characteristics of its tax system (tax burden and fiscal freedom) but also the institutional characteristics such as property rights protection, freedom from corruption, along with investment and financial freedom. Depending on their scores, countries are assessed and divided into the following groups:

- free countries, with index values between 80 and 100;

- mostly free, 70-79.9;

- moderately free, 60-69.9; 
- mostly unfree, 50-59.9; and

- repressed, 0-49.9.

The index of tax burden characterizes the degree of tax system's impact on the ease of doing business in a specific country. The values of this index may vary from zero and 100. The higher the index, the more attractive the country is for business.

According to Carlsson and Lundström (2002), draw attention to the fact that most studies on the relationship between economic freedom and GDP growth have shown a positive relationship. However, an important problem in this area is the identification of measures that the governments use to achieve or sustain economic freedom. The index is aggregated, so it is difficult to identify individual political or economic instruments. Similar ideas appear in Gehring (2012), Rode and Coll (2012), and others. This means that the index of economic freedom is an adequate indicator of the description of the economic development of a country.

According to Berggren (2003) assert that economic freedom can be an explanation for economic growth and income distribution. That is why the index of economic freedom can be an independent variable in econometric models. At the same time, it should be considered that economic freedom is also influenced by other factors such as democracy, political freedom and wealth; in this case, the index of economic freedom is a dependent variable. Since changes in taxation affect business activity, economic wealth, poverty, and other factors, the tax-to-GDP ratio can be used as an independent variable and the index of economic freedom as a dependent variable.

Fiscal freedom is a measure of tax burden imposed by a government. It includes marginal direct tax rates, and overall taxes, including all forms of direct and indirect taxation at all levels of government as a percentage of GDP. Thus, fiscal freedom is composed of three quantitative factors:

- top marginal tax rate on individual income;

- top marginal tax rate on corporate income; and

- total tax burden as a percentage of GDP.

In scoring fiscal freedom, each of these numerical variables is weighted equally as one-third (Index of Economic Freedom, 2019).

The index of fiscal freedom shows tax burden and reflects institutional changes in taxation. Thus, the analysis of taxation's impact (tax-to-GDP ratio) on fiscal freedom 
allows us to better understand whether tax reforms agree with the institutional environment of the country.

\section{The Evolution of Taxation in Ukraine}

A brief historical overview of taxation in Ukraine is necessary in order to gain a better understanding of the problems Ukrainian reformers sought to address. Originally, Ukrainian tax legislation had a two-level structure: there was the General Law on the Taxation System and laws for specific taxes such as VAT, corporate income tax, or personal income tax. The General Law on the Taxation System (revised in 1991, 1994, and 1997) determined the structure of tax system and defined the general principles of taxation. Since 2011, tax legislation has been codified. In 2015, the Tax Code was substantially amended.

In general, Ukrainian taxation reforms can be classified into four stages. At the initial stage in the development of the country's tax system (1991-1997), the key priority was to establish a tax system able to ensure stable budget revenues. At this stage, the fiscal function prevailed in government thinking, although some steps were taken to reduce tax burden. Rates were reduced for key taxes: first, the VAT rate was lowered from $28 \%$ to $20 \%$ in 1995 , which was a bold decision considering the level of budget deficit at that time. Let us note that there was an attempt to set the VAT rate at $20 \%$ in 1993, but it proved too hard to retain the rate at this level, so it had to be raised after only four and a half months.

At the same time, the rates of business taxes were lowered. Initially, the corporate income tax rate on net profit was set at 35\%. In 1992-1994, the system of business taxation changed several times: income tax (the sum of commercial profit and wage fund minus gross income) had a rate of $18 \%$; in 1994, it was raised to $22 \%$; later, this tax was replaced by a corporate income tax of $30 \%$. Finally, the government decided to set the tax rate on corporate profits at $30 \%$.

Furthermore, personal income taxation also underwent significant changes. At first, there was a "citizen income tax" but, later, it was renamed into "tax on the income of individuals;" tax rates and mechanisms of taxation were also adjusted multiple times. The situation was particularly volatile in the early 1990s. Until 2003, Ukraine had a progressive tax scale, which changed three times. 
The second stage (1997-2000) involved the development of tax regulation and harmonization of main taxes with international norms. In 1997, the principles of VAT and corporate income tax collection were revised, and the principles of VAT collection were harmonized with those of western countries. As for corporate income tax, the reform resulted in the separation of bookkeeping from tax accounting, and profit started to be calculated differently from the way profit is calculated in bookkeeping, which resulted in an unmanageable situation, since corrected. The introduction of a simplified taxation system for small businesses - which stimulated entrepreneurship and self-employment - was one of the positive aspects of tax regulation in this period.

At the third stage of the reforms (2000-2010), policymakers sought the right balance between the fiscal and regulating function of taxes; for example, excessive VAT benefits and corporate income tax benefits were liquidated. In the same period, the progressive personal income tax scheme was replaced by a proportional scheme. From 2004 to 2007, the proportional tax rate in Ukraine was $13 \%$, but in 2007 it was raised to $15 \%$. One of the most significant results of the reforms in this period was the adoption of the law “On the Procedure for Payment of Taxpayers' Liabilities to Budgets and State Purposed Funds" of 21 December 2000 No. 2181. This law systematized approaches to tax liability settlement and to the application of penalties for violating tax legislation. Principles of penalizing taxpayers changed considerably; moreover, the grounds for imposing penalties were expanded, and the size of penalties became dependent on the type of tax check and the kind of violation.

The fourth stage (from 2011 to date) involved the codification of tax legislation, the simplification of the tax system, and its further harmonization with EU legislation. The search for ways to further reduce tax burden continues.

The modern Ukrainian tax system consists of five central government taxes, two local taxes, and two local fees. Central government taxes include corporate income tax, personal income tax, value-added tax, excise tax, ecological tax, and fees (Table 1).

Local taxes include property taxes and a unified tax. Property tax is levied on real estate, land, and cars. The unified tax is paid by small businesses. Local fees consist of parking and tourist fees. Local taxes do not have significant fiscal effectiveness.

To provide state pension insurance, employers pay a unified social security contribution. The unified social security contribution is not included in the tax system. This payment is regulated by a separate law. 
Table 1. Central Government Taxes in Ukraine

\begin{tabular}{|c|c|c|}
\hline Tax & Tax rates & The object of taxation \\
\hline $\begin{array}{l}\text { Corporate } \\
\text { income tax }\end{array}$ & 18 & $\begin{array}{l}\text { Profit, which is calculated based on accounting data } \\
\text { and adjusted for tax differences. Main tax differences are } \\
\text { related to depreciation, provisions, and financial transactions. }\end{array}$ \\
\hline $\begin{array}{l}\text { Personal } \\
\text { income tax }\end{array}$ & 18 & Gross personal income from all sources. \\
\hline $\begin{array}{l}\text { Value added } \\
\text { tax }\end{array}$ & $\begin{array}{l}20 \% \text { is the basic rate; } \\
7 \% \text { is the rate for } \\
\text { medical goods }\end{array}$ & $\begin{array}{l}\text { Goods delivery, providing services, and conducting work. } \\
\text { VAT is levied using the same methodology as in EU countries. }\end{array}$ \\
\hline Excise tax & Fixed and ad valorem & Excisable goods are alcohol and tobacco products, cars, and fuel. \\
\hline $\begin{array}{l}\text { Ecological } \\
\text { tax }\end{array}$ & Differentiated rates & $\begin{array}{l}\text { The amount of emission of harmful substances or disposed } \\
\text { waste. }\end{array}$ \\
\hline $\begin{array}{l}\text { Fees } \\
\text { (rent } \\
\text { payments) }\end{array}$ & Differentiated rates & $\begin{array}{l}\text { The use of land for the extraction of minerals, the use of subsoil } \\
\text { for purposes other than mining, the use of Ukrainian radio } \\
\text { frequency resources, the special use of water, the special use } \\
\text { of forest resources, rent payment for the transportation of oil } \\
\text { and oil products by oil pipelines, the transit of ammonia } \\
\text { by pipelines through Ukrainian territory. }\end{array}$ \\
\hline
\end{tabular}

Source: own elaboration.

Instability in Ukrainian tax legislation can be explained by many factors. One of the key factors was that the country lacked the necessary experience required for the formation of statehood attributes, in particular a tax system. Presently, the structure of tax systems in different countries is approximately the same, which is particularly true for the range of taxes and mechanisms of taxation in EU countries. Therefore, as a newly independent and inexperienced country, Ukraine could benefit from the experience of developed countries. However, some adjustments had to be made regarding the country's peculiar needs and specificities in order to build an efficient, reliable, and stable tax system. Even though tax systems of different countries share the same principles, no two systems are identical. Therefore, it would have been unreasonable to expect the newly emerging Ukrainian tax system to be free of issues at the beginning.

Subjective factors included the low quality of draft laws and their ill-advised adoption. For example, the draft Tax Code was first presented for adoption to Ukraine's parliament (Verkhovna Rada) in 2000 and subsequently mired in an approval process lasting until 2010, when the government was forced to rush through a third version of the law. According to Oparin and Paientko (2017), each new Ukrainian government 
- including the current one - instituted its own tax reforms, which invites the supposition that the government's prime concern is not about tax efficiency or the quality of tax legislation but lobbying for self-interests of the legislators.

\section{Research Results}

\section{Comparative Analysis of Tax Burden in Ukraine and OECD Countries}

\section{General Characteristic}

A high tax burden is generally considered to have been one of the major drawbacks of the Ukrainian tax system throughout its development. Therefore, the first question needed to be answered here is whether tax burden in Ukraine is indeed high or not. There is a widely shared misconception held by Ukrainian citizens about the excessive number of taxes in Ukraine. However, each round of tax reforms in this country included eliminating some of the taxes, when the Tax Code was adopted or amended. As a rule, these were the taxes of secondary importance or those that produced little revenue. A really important matter was the cancelation of contributions to different special budget funds, in particular those that created a substantial tax burden such as the Fund for the Liquidation of Chernobyl Disaster Consequences, the Social Security Fund, the State Innovation Fund, and the Fund for Road Construction and Repair. Such funds were created in large numbers in the first year of Ukraine's independence. Expenditures financed from these funds were included in various lines of government expenditures. In other words, programs financed from these funds continue to receive financing, although the targeted charges for their financing have been canceled. Currently, the most significant one remaining is the contribution to the Fund of Social Security of the Disabled, paid as a penalty if disabled people are not employed by a company of a certain size.

The level of tax burden is measured as a percentage of GDP and by comparing tax rates for key taxes. Since the question about whether to include social contributions into tax burden or not remains open, we compare tax burden (as a ratio of tax revenues to GDP) in Ukraine and OECD countries (see Table 2, Figure 1). For Ukraine, we consider the period starting from 2004, which is when the necessary information was first made publicly accessible.

The graph in Figure 1 shows that the share of tax revenues in GDP was the smallest in 2004 and the highest in 2012. Revenues from the entire general government sector were included in calculations. The mean value in the given period is $36.35 \%$. Public 
sector indicators are also included in the calculations, as public entities also pay taxes on a general basis. As can be seen from graphs in Figure 1, the share of tax revenues in GDP in Ukraine is constantly changing, which is partly due to changes in tax legislation. In 2011, the Tax Code came into force, as a result of which some taxes were removed, and the corporate income tax rate was reduced. In 2011-2014, the corporate tax rate was reduced from $25 \%$ to $18 \%$. Furthermore, in 2011, a unified social contribution was introduced in Ukraine, which combined contributions to four funds: Pension Fund, Social Insurance Fund for Temporary Disability, Social Insurance Fund for Unemployment, and Social Insurance Fund for Work-Related Accidents. Therefore, from 2011 to 2014, there is a decrease in the share of tax revenue in GDP in Ukraine.

Figure 1. The share of tax revenues in the GDP of Ukraine in 2004-2018, in \%

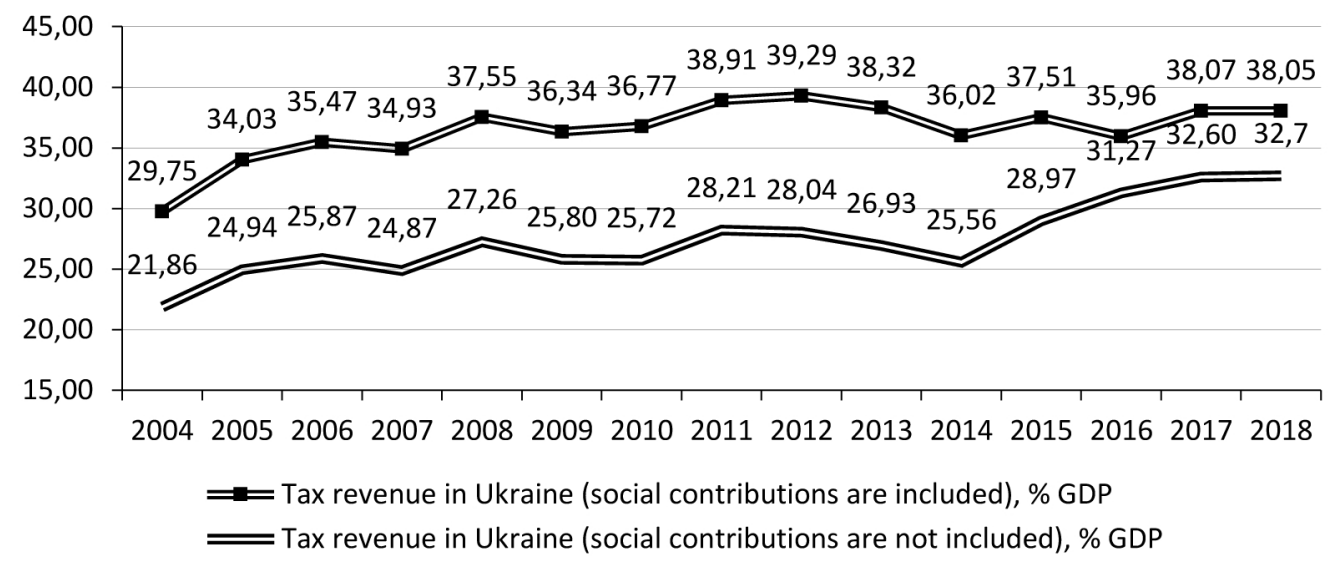

Source: own elaboration of World Bank data.

Excluding social insurance contributions from 2014, the increase in the share of tax revenue is due to the introduction of a military charge, the introduction of an additional VAT rate of $7 \%$ on medical goods, and the introduction of electronic VAT administration. Table 2 shows results of the statistical analysis of tax burden in OECD countries.

We see above that Ukraine has no abnormal deviations from the global trend concerning tax burden: in the given period, its tax burden remained within the range of $21.86-32.06 \%$ in the net of social security contributions and $29.75-39.29 \%$ including social security contributions. The tax burden in Ukraine is below average among OECD countries and is at approximately the same level as that of the Czech Republic, Germany, Iceland, the Netherlands, Poland, Portugal, and the Slovak Republic. Therefore, the opinion that tax burden in Ukraine is high appears ungrounded. Thus, 
Ukraine can be described as a country with a medium level of tax burden. The tax burden of key taxes is analyzed below.

Table 2. Descriptive statistics on tax revenues in OECD countries in 1995-2018, in \% of GDP, by country

\begin{tabular}{|c|c|c|c|c|c|c|c|c|}
\hline Year & mean & sd & $\min$ & q1 & median & q3 & $\max$ & IQD \\
\hline Austria & 42.076 & 0.991 & 40.408 & 41.195 & 42.233 & 42.704 & 43.886 & 1.509 \\
\hline Belgium & 43.569 & 0.788 & 42.370 & 43.081 & 43.451 & 44.083 & 45.106 & 1.062 \\
\hline Canada & 33.056 & 1.605 & 30.875 & 31.791 & 32.766 & 34.473 & 35.912 & 2.682 \\
\hline Chile & 19.784 & 1.310 & 17.334 & 18.943 & 19.591 & 20.554 & 22.710 & 1.611 \\
\hline the Czech Republic & 33.571 & 0.795 & 32.283 & 33.177 & 33.454 & 34.224 & 34.893 & 1.047 \\
\hline Denmark & 46.247 & 1.028 & 44.756 & 45.547 & 46.189 & 46.720 & 48.531 & 1.172 \\
\hline Estonia & 32.347 & 1.596 & 29.969 & 31.192 & 31.667 & 33.519 & 36.033 & 2.327 \\
\hline Finland & 43.170 & 1.472 & 40.788 & 42.073 & 43.333 & 44.138 & 45.820 & 2.064 \\
\hline France & 43.523 & 1.297 & 41.528 & 42.409 & 43.334 & 44.304 & 46.231 & 1.895 \\
\hline Germany & 35.654 & 1.059 & 33.860 & 34.948 & 35.574 & 36.316 & 37.544 & 1.368 \\
\hline Greece & 32.741 & 3.014 & 27.890 & 30.803 & 31.982 & 34.901 & 39.386 & 4.098 \\
\hline Hungary & 38.070 & 1.115 & 36.250 & 37.313 & 37.950 & 38.828 & 40.776 & 1.514 \\
\hline Iceland & 36.097 & 4.220 & 31.187 & 33.998 & 35.592 & 37.142 & 51.595 & 3.144 \\
\hline Ireland & 28.470 & 2.652 & 22.837 & 27.358 & 28.458 & 30.796 & 32.268 & 3.437 \\
\hline Israel & 32.931 & 1.823 & 29.834 & 31.221 & 33.331 & 34.308 & 35.421 & 3.087 \\
\hline Italy & 41.305 & 1.532 & 38.583 & 40.165 & 41.668 & 42.228 & 44.050 & 2.063 \\
\hline Korea & 22.873 & 2.278 & 19.118 & 21.620 & 23.391 & 24.617 & 26.900 & 2.998 \\
\hline Latvia & 28.861 & 1.065 & 27.466 & 27.950 & 28.646 & 29.470 & 31.222 & 1.520 \\
\hline Lithuania & 29.298 & 1.662 & 26.966 & 27.965 & 29.203 & 30.152 & 32.758 & 2.187 \\
\hline Luxembourg & 32.067 & 1.018 & 34.850 & 36.502 & 37.325 & 37.632 & 38.654 & 1.130 \\
\hline Mexico & 12.511 & 1.765 & 9.912 & 11.511 & 12.467 & 12.803 & 16.634 & 1.293 \\
\hline the Netherlands & 36.243 & 1.110 & 34.804 & 35.515 & 36.047 & 37.027 & 38.752 & 1.512 \\
\hline New Zealand & 32.613 & 1.705 & 30.055 & 31.572 & 32.313 & 33.816 & 36.058 & 2.245 \\
\hline Norway & 41.047 & 1.420 & 38.228 & 40.024 & 41.850 & 42.059 & 42.831 & 2.035 \\
\hline Poland & 33.404 & 1.638 & 31.199 & 32.010 & 32.940 & 34.383 & 36.617 & 2.373 \\
\hline
\end{tabular}




\begin{tabular}{|c|c|c|c|c|c|c|c|c|}
\hline Portugal & 31.601 & 1.658 & 29.278 & 30.290 & 31.247 & 30.073 & 34.708 & 1.783 \\
\hline the Slovak Republic & 32.185 & 3.222 & 28.075 & 29.258 & 32.179 & 33.263 & 39.562 & 4.005 \\
\hline Slovenia & 36.878 & 0.611 & 36.021 & 36.406 & 36.822 & 37.263 & 38.360 & 0.857 \\
\hline Spain & 32.944 & 1.538 & 29.708 & 32.014 & 33.077 & 33.593 & 36.358 & 1.579 \\
\hline Sweden & 45.269 & 2.111 & 42.506 & 43.588 & 45.174 & 46.724 & 48.984 & 3.136 \\
\hline Switzerland & 26.819 & 0.685 & 25.519 & 26.507 & 26.882 & 27.016 & 28.456 & 0.509 \\
\hline Turkey & 23.368 & 2.382 & 16.390 & 23.104 & 23.592 & 25.017 & 25.899 & 1.914 \\
\hline the United Kingdom & 31.966 & 1.105 & 29.311 & 31.504 & 32.283 & 32.705 & 33.258 & 1.201 \\
\hline $\begin{array}{l}\text { the United States } \\
\text { of America }\end{array}$ & 25.919 & 1.464 & 23.017 & 24.782 & 25.975 & 27.049 & 28.202 & 2.266 \\
\hline
\end{tabular}

Source: own elaboration of OECD data.

\section{Corporate Income Tax}

The tax-to-GDP ratios for key taxes in Ukraine are also far from the highest. For instance, the corporate income tax-to-GDP ratio is even lower than in many OECD countries (see Table 3).

The corporate income tax-to-GDP ratio in Ukraine is lower than in Chile, Canada, Belgium, New Zealand, and Norway. Since 2015, the corporate income tax-to-GDP ratio in Ukraine has been lower than the mean corporate income tax-to-GDP ratio in OECD. It should be noted that the Ukrainian government has been continuously declaring that the stimulation of business and attraction of investment are its top priorities, although no significant reduction in profit tax rates ever ensued. The corporate income tax rate was reduced very slowly and, therefore, had no visible effect either on taxpayers or the country in general.

Effective corporate income tax rates in all OECD countries are lower than nominal due to tax benefits and preferences applied for certain transactions. In the majority of these countries, both nominal and effective corporate income tax rates are higher than in Ukraine, which clearly disproves the common misconception about the high level of corporate taxation in Ukraine. In some countries, such as Ireland, Switzerland, and Germany, the corporate income tax rates are lower than in Ukraine, but the fiscal significance of this tax is higher, which can be related to the mechanisms of providing tax preferences or the level of shadow economy. In these countries, this level on average does not exceed 20\%, while in Ukraine, according to the Ministry of Economic Development and Trade, in the first quarter of 2017, the level of shadow economy reached $37 \%$ 
(Shadow Economy in Ukraine, 2019). This indicator is even higher if we look at World Bank estimates, which show that in the last five years, the level of shadow economy in Ukraine has been hovering at around $50-60 \%$. Due to tax evasion, this level has a negative impact on the fiscal efficiency of taxes.

Table 3. Corporate income tax-to-GDP ratio in OECD countries and Ukraine in 2010-2018, in \%

\begin{tabular}{|c|c|c|c|c|c|c|c|c|c|}
\hline Country & 2010 & 2011 & 2012 & 2013 & 2014 & 2015 & 2016 & 2017 & 2018 \\
\hline Austria & 1.9 & 2.0 & 2.0 & 2.2 & 2.1 & 2.2 & 2.4 & 2.5 & 2.7 \\
\hline Belgium & 2.5 & 2.8 & 3.0 & 3.1 & 3.1 & 3.3 & 3.4 & 4.1 & 4.4 \\
\hline Canada & 3.2 & 3.2 & 3.2 & 3.3 & 3.3 & 3.4 & 3.7 & 3.7 & 3.7 \\
\hline Chile & 4.0 & 4.9 & 5.8 & 4.4 & 4.2 & 4.3 & 4.2 & 4.3 & 4.7 \\
\hline the Czech Republic & 3.2 & 3.2 & 3.3 & 3.4 & 3.5 & 3.6 & 3.7 & 3.7 & 3.5 \\
\hline Denmark & 2.3 & 2.2 & 2.6 & 2.8 & 2.8 & 2.8 & 2.8 & 3.3 & 2.9 \\
\hline Estonia & 1.3 & 1.2 & 1.4 & 1.7 & 1.7 & 2.1 & 1.7 & 1.5 & 2.0 \\
\hline Finland & 2.4 & 2.6 & 2.1 & 2.4 & 1.9 & 2.2 & 2.2 & 2.7 & 2.6 \\
\hline France & 2.3 & 2.6 & 2.6 & 2.6 & 2.3 & 2.1 & 2.0 & 2.3 & 2.1 \\
\hline Germany & 1.5 & 1.7 & 1.7 & 1.8 & 1.7 & 1.7 & 2.0 & 2.0 & 2.1 \\
\hline Greece & 2.5 & 2.1 & 1.1 & 1.1 & 1.9 & 2.1 & 2.5 & 1.9 & 1.9 \\
\hline Hungary & 1.2 & 1.2 & 1.3 & 1.4 & 1.6 & 1.8 & 2.3 & 2.1 & 1.2 \\
\hline Iceland & 0.9 & 1.7 & 1.8 & 2.1 & 3.2 & 2.3 & 2.5 & 3.1 & 2.5 \\
\hline Ireland & 2.4 & 2.2 & 2.3 & 2.4 & 2.4 & 2.6 & 2.7 & 2.8 & 3.2 \\
\hline Israel & 2.6 & 3.0 & 2.7 & 3.5 & 3.2 & 3.0 & 3.1 & 3.3 & 3.2 \\
\hline Italy & 2.3 & 2.2 & 2.4 & 2.6 & 2.2 & 2.0 & 2.1 & 2.1 & 1.9 \\
\hline Korea & 3.2 & 3.7 & 3.7 & 3.4 & 3.2 & 3.3 & 3.6 & 3.8 & 4.5 \\
\hline Latvia & 1.0 & 1.4 & 1.6 & 1.6 & 1.5 & 1.6 & 1.7 & 1.6 & 1.0 \\
\hline Lithuania & 1.0 & 0.8 & 1.3 & 1.4 & 1.4 & 1.5 & 1.6 & 1.5 & 1.5 \\
\hline Luxembourg & 5.8 & 5.0 & 5.1 & 4.8 & 4.3 & 4.5 & 4.6 & 5.2 & 5.9 \\
\hline Mexico & 1.8 & 2.1 & 1.8 & 2.4 & 2.5 & 3.2 & 3.5 & 3.5 & 3.4 \\
\hline the Netherlands & 2.3 & 2.2 & 2.1 & 2.2 & 2.5 & 2.7 & 3.3 & 3.3 & 3.5 \\
\hline New Zealand & 3.7 & 3.9 & 4.5 & 4.4 & 4.2 & 4.4 & 4.9 & 4.7 & 5.1 \\
\hline Norway & 9.9 & 10.8 & 10.3 & 8.2 & 6.6 & 4.5 & 4.0 & 4.9 & 6.0 \\
\hline
\end{tabular}




\begin{tabular}{|c|c|c|c|c|c|c|c|c|c|}
\hline Poland & 1.9 & 2.0 & 2.1 & 1.8 & 1.7 & 1.8 & 1.8 & 1.9 & 2.1 \\
\hline Portugal & 2.7 & 3.1 & 2.7 & 3.3 & 2.8 & 3.1 & 3.0 & 3.2 & 3.4 \\
\hline the Slovak Republic & 2.5 & 2.4 & 2.4 & 2.9 & 3.3 & 3.7 & 3.5 & 3.4 & 3.2 \\
\hline Slovenia & 1.8 & 1.7 & 1.2 & 1.2 & 1.4 & 1.5 & 1.6 & 1.8 & 1.9 \\
\hline Spain & 1.9 & 1.9 & 2.2 & 2.1 & 2.1 & 2.4 & 2.3 & 2.3 & 2.5 \\
\hline Sweden & 3.3 & 3.1 & 2.6 & 2.6 & 2.7 & 2.9 & 2.7 & 2.8 & 3.0 \\
\hline Switzerland & 2.7 & 2.8 & 2.8 & 2.8 & 2.8 & 3.0 & 3.1 & 3.1 & 3.0 \\
\hline Turkey & 1.8 & 1.9 & 1.8 & 1.6 & 1.6 & 1.4 & 1.6 & 1.7 & 2.1 \\
\hline the United Kingdom & 2.9 & 2.8 & 2.7 & 2.6 & 2.5 & 2.4 & 2.7 & 2.8 & 2.9 \\
\hline $\begin{array}{l}\text { the United States } \\
\text { of America }\end{array}$ & 1.8 & 1.8 & 2.0 & 2.1 & 2.3 & 2.1 & 2.0 & 1.7 & 1.1 \\
\hline Sample Mean & 2.61 & 2.71 & 2.71 & 2.70 & 2.66 & 2.69 & 2.80 & 2.90 & 2.96 \\
\hline Ukraine & 3.73 & 4.18 & 3.96 & 3.78 & 2.57 & 1.97 & 2.54 & 2.48 & 2.52 \\
\hline
\end{tabular}

Source: own elaboration of OECD and World Bank data.

As for corporate income tax, its rate was gradually lowered, and in 2005-2010 the tax rate was $25 \%$. In accordance with the Tax Code of 2010, the tax rate was planned to be lowered to $23 \%$ in 2011 ; to $21 \%$ in 2012 ; to $19 \%$ in 2013 ; and to $16 \%$ in 2014 . These plans were never fully implemented and, at the moment, the corporate income tax rate remains at $18 \%$. Thus, since Ukraine became an independent state, the tax rate was almost halved. Compared with other countries, this rate is generally on a par with that of other post-communist countries, but significantly lower than that of developed countries.

In addition to the above, tax burden was also lowered due to changes in corporate income taxation. Since 2015, taxable income is defined as the financial result calculated according to national accounting standards and international financial reporting standards, which depend on local application. Thus, financial results calculated with the above method are further adjusted for tax differences defined in the Tax Code of Ukraine. The main tax differences are those related to the depreciation of non-current assets, financing transactions, and provisions for incurred and probable expenses. This approach does not contradict existing international practice but, on the contrary, is methodologically close to the international practice. However, in Ukraine, this change caused creates a conflict between taxpayers and tax authorities. What in fact happened is that, since 1997, tax accounting prevailed over bookkeeping, which remained relevant only for the companies subject to mandatory audits and, thus, required to publish 
their financial reports, such as issuers of securities, financial institutions, and public joint-stock companies. In OECD countries continue corporate tax rate cuts, led by countries with high tax rates. EU and OECD countries are working on the implementation of BEPS rules, which stands for base erosion and profit shifting (Tax Policy Reforms, 2019; Taxation trends in EU, 2019).

\section{Personal Income Tax}

Personal income tax can be considered less harmonized than the corporate income tax. Since 2007, the rate of Ukraine's personal income tax was 15\% and, in 2011, a second rate of $17 \%$ was introduced for higher-income individuals. In 2016, a single rate of $18 \%$ was instituted. At the same time, the unified social security contribution was canceled for employees. Such instability in tax law may signify a lack of clear strategic and tactical vision behind the tax reforms. We also notice a perceptible lack of agreement among policymakers as to what direction reform should take; for example, high-income groups now enjoy a proportionally lower level of taxation, while disadvantaged groups, on the contrary, are struggling with higher taxation levels. In comparison with other countries, Ukraine has the lowest level of personal income tax in the world. Most countries have fixed progressive tax schedules. In Western Europe, tax burden on personal income is reduced considerably through tax deductions and tax rebates. First, in almost all countries, there is a tax-exempt minimum income, which either equals or slightly exceeds the minimum wage. In Ukraine, only a limited number of people can take advantage of the full scope of tax benefits.

Second, western states strive to promote self-employment and, therefore, offer self-employed citizens an opportunity to deduct their home office expenses and expenses of operating their personal vehicles for business against their self-employment income, thereby reducing their income tax. To claim self-employed tax benefits, citizens do not have to be registered as entrepreneurs. However, there is no such option in Ukraine.

The current practice of personal income taxation in Ukraine is inconsistent with the government's intention to stimulate the development of non-state pension schemes. The only incentive available in Ukraine is the right to claim tax deduction and, even in this case, there is a limit on the amount of pension contributions for which one might obtain a tax deduction. In many EU countries - like Germany, France, and the UK - governments stimulate contributions to private pension plans by incentivizing the employer and the insured. For instance, in the progressive income tax system, individuals are entitled to a higher tax threshold or to tax deduction on their pension contributions. In OECD countries, small cuts in personal income taxes for low - and middle-income earners were implemented (Tax Policy Reforms, 2019; Taxation trends 
in EU, 2019). Unfortunately, this concept is absent in Ukraine. The personal income tax-to-GDP ratio in OECD countries and in Ukraine are presented in Table 4.

Table 4. Personal income tax-to-GDP ratio in OECD countries and Ukraine in 2010-2018, in $\%$

\begin{tabular}{|c|c|c|c|c|c|c|c|c|c|}
\hline Country & 2010 & 2011 & 2012 & 2013 & 2014 & 2015 & 2016 & 2017 & 2018 \\
\hline Austria & 9.2 & 9.2 & 9.5 & 9.7 & 10.0 & 10.3 & 9.1 & 9.1 & 9.4 \\
\hline Belgium & 12.0 & 12.2 & 12.3 & 12.9 & 13.0 & 12.6 & 12.1 & 12.1 & 12.1 \\
\hline Canada & 10.9 & 11.1 & 11.4 & 11.3 & 11.4 & 12.1 & 11.9 & 11.7 & 12.0 \\
\hline Chile & 1.3 & 1.4 & 1.5 & 1.4 & 1.4 & 2.0 & 1.8 & 1.9 & 1.4 \\
\hline the Czech Republic & 3.3 & 3.5 & 3.6 & 3.7 & 3.6 & 3.6 & 3.8 & 4.0 & 4.3 \\
\hline Denmark & 23.2 & 23.2 & 23.3 & 25.0 & 26.2 & 25.3 & 24.3 & 24.2 & 24.4 \\
\hline Estonia & 5.3 & 5.1 & 5.2 & 5.4 & 5.7 & 5.7 & 5.8 & 5.7 & 5.5 \\
\hline Finland & 12.0 & 12.3 & 12.5 & 12.8 & 13.4 & 13.3 & 13.0 & 12.6 & 12.3 \\
\hline France & 7.2 & 7.4 & 8.0 & 8.4 & 8.5 & 8.5 & 8.6 & 8.6 & 9.5 \\
\hline Germany & 8.5 & 8.8 & 9.4 & 9.6 & 9.6 & 9.8 & 9.9 & 10.2 & 10.4 \\
\hline Greece & 4.0 & 4.8 & 7.0 & 6.0 & 5.9 & 5.7 & 5.9 & 6.2 & - \\
\hline Hungary & 6.5 & 5.0 & 5.6 & 5.3 & 5.2 & 5.3 & 5.2 & 5.4 & 5.2 \\
\hline Iceland & 11.8 & 12.5 & 12.7 & 13.2 & 13.0 & 13.0 & 13.5 & 14.3 & 14.5 \\
\hline Ireland & 8.1 & 8.5 & 8.9 & 9.0 & 9.1 & 7.3 & 7.4 & 7.0 & 7.0 \\
\hline Israel & 5.5 & 5.5 & 5.4 & 5.4 & 5.7 & 6.1 & 6.2 & 6.7 & 6.4 \\
\hline Italy & 11.3 & 11.0 & 11.6 & 11.6 & 11.2 & 11.2 & 10.9 & 10.8 & 10.8 \\
\hline Japan & 4.9 & 5.1 & 5.2 & 5.5 & 5.7 & 5.8 & 5.7 & 5.9 & 6.0 \\
\hline Korea & 3.3 & 3.5 & 3.7 & 3.7 & 4.0 & 4.3 & 4.6 & 4.8 & 5.2 \\
\hline Latvia & 6.2 & 5.6 & 5.7 & 5.8 & 5.9 & 5.9 & 6.3 & 6.6 & 5.9 \\
\hline Lithuania & 3.6 & 3.5 & 3.5 & 3.6 & 3.6 & 3.8 & 4.0 & 3.9 & 4.1 \\
\hline Luxembourg & 7.9 & 8.2 & 8.4 & 8.7 & 8.7 & 9.1 & 9.4 & 9.1 & 9.5 \\
\hline Mexico & 2.3 & 2.4 & 2.5 & 2.6 & 2.9 & 3.3 & 3.4 & 3.4 & 3.4 \\
\hline the Netherlands & 7.7 & 7.4 & 6.9 & 6.8 & 6.9 & 7.6 & 7.1 & 8.3 & 8.0 \\
\hline New Zealand & 11.4 & 10.8 & 11.7 & 11.2 & 11.7 & 11.8 & 11.7 & 12.1 & 12.1 \\
\hline Norway & 9.9 & 9.7 & 9.7 & 9.9 & 9.8 & 10.8 & 10.7 & 10.3 & 9.9 \\
\hline
\end{tabular}




\begin{tabular}{|c|c|c|c|c|c|c|c|c|c|}
\hline Poland & 4.4 & 4.3 & 4.5 & 4.5 & 4.6 & 4.7 & 4.8 & 5.0 & 5.3 \\
\hline Portugal & 5.4 & 6.0 & 5.8 & 7.7 & 7.7 & 7.3 & 6.8 & 6.5 & 6.6 \\
\hline the Slovak Republic & 2.6 & 2.8 & 2.9 & 2.9 & 3.0 & 3.1 & 3.3 & 3.4 & 3.6 \\
\hline Slovenia & 5.6 & 5.6 & 5.7 & 5.1 & 5.1 & 5.1 & 5.2 & 5.1 & 5.3 \\
\hline Spain & 6.8 & 7.1 & 7.4 & 7.5 & 7.6 & 7.2 & 7.1 & 7.3 & 7.6 \\
\hline Sweden & 12.0 & 11.7 & 11.9 & 12.2 & 12.2 & 12.5 & 13.2 & 13.3 & 12.7 \\
\hline Switzerland & 8.5 & 8.4 & 8.5 & 8.4 & 8.3 & 8.6 & 8.6 & 8.6 & 8.5 \\
\hline Turkey & 3.5 & 3.5 & 3.6 & 3.5 & 3.6 & 3.7 & 3.7 & 3.6 & 3.8 \\
\hline the United Kingdom & 9.3 & 9.3 & 8.9 & 8.9 & 8.7 & 8.9 & 9.0 & 9.1 & 9.1 \\
\hline the United States & 8.2 & 9.3 & 9.2 & 9.9 & 10.1 & 10.6 & 10.4 & 10.4 & 9.9 \\
\hline OECD Average & 7.6 & 7.7 & 7.9 & 8.0 & 8.2 & 8.3 & 8.2 & 8.3 & 8.3 \\
\hline Ukraine & 4.7 & 4.6 & 4.7 & 4.7 & 4.7 & 5.0 & 5.8 & 6.2 & 6.4 \\
\hline
\end{tabular}

Source: own elaboration of OECD and World Bank data.

The last step towards the reduction of tax burden in Ukraine was cutting the rate of the unified social contribution for enterprises. While it previously varied between $36.76 \%$ to $49.7 \%$ of the salary budget, depending on the occupational hazard class, in 2016 the rate was reduced by more than half, to $22 \%$. Much had been said about the need for such a measure long before it was introduced, one of the arguments being the experience of developed countries, where the average rate of social security contributions is $18-20 \%$. Nevertheless, such comparisons are flawed, since most of the countries where this rate is applied have funded pension systems, while Ukraine has a PAYG (Pay-as-you-go or PAYE - pay-as-you-earn) system. As Oparin and Paientko (2017) indicate, it is more effective to combine lowering of the unified social tax rate with a more radical reform of the pension system which, unlike the one of 2017, is more likely to lead to fundamental improvements. Furthermore, many taxpayers had to face a significant expansion of the tax base through the unified social tax, which included most of compensation payments such as compensation for rent payments.

\section{Value Added Tax}

The dynamics of VAT burden and its reform trends are different from those described above (see Table 5). 
Table 5. VAT-to-GDP ratio in OECD countries and Ukraine in 2010-2018, in \%

\begin{tabular}{|c|c|c|c|c|c|c|c|c|c|}
\hline Country & 2010 & 2011 & 2012 & 2013 & 2014 & 2015 & 2016 & 2017 & 2018 \\
\hline Austria & 7.7 & 7.6 & 7.7 & 7.7 & 7.6 & 7.6 & 7.7 & 7.7 & 7.6 \\
\hline Belgium & 6.9 & 6.9 & 6.9 & 6.9 & 6.9 & 6.7 & 6.8 & 6.8 & 6.9 \\
\hline Canada & 4.2 & 4.2 & 4.3 & 4.1 & 4.1 & 4.4 & 4.5 & 4.5 & 4.5 \\
\hline Chile & 7.5 & 7.8 & 8.0 & 8.1 & 8.2 & 8.3 & 8.3 & 8.4 & 8.5 \\
\hline Czech Republic & 6.6 & 6.9 & 7.0 & 7.4 & 7.4 & 7.3 & 7.4 & 7.7 & 7.7 \\
\hline Denmark & 9.4 & 9.5 & 9.5 & 9.2 & 9.2 & 9.2 & 9.4 & 9.5 & 9.7 \\
\hline Estonia & 8.5 & 8.2 & 8.4 & 8.2 & 8.5 & 9.1 & 9.1 & 9.1 & 9.1 \\
\hline Finland & 8.3 & 8.8 & 9.0 & 9.3 & 9.2 & 9.0 & 9.1 & 9.1 & 9.2 \\
\hline France & 6.8 & 6.8 & 6.8 & 6.8 & 6.9 & 6.9 & 6.9 & 7.0 & 7.2 \\
\hline Germany & 7.0 & 7.0 & 7.0 & 7.0 & 6.9 & 7.0 & 6.9 & 6.9 & 7.0 \\
\hline Greece & 7.1 & 7.3 & 7.2 & 7.0 & 7.1 & 7.3 & 8.1 & 8.1 & 8.1 \\
\hline Hungary & 8.5 & 8.4 & 9.1 & 8.9 & 9.2 & 9.6 & 9.3 & 9.5 & 9.3 \\
\hline Iceland & 7.3 & 7.5 & 7.8 & 7.6 & 7.8 & 8.0 & 8.2 & 8.9 & 8.3 \\
\hline Ireland & 6.0 & 5.7 & 5.8 & 5.8 & 5.9 & 4.5 & 4.7 & 4.4 & 4.4 \\
\hline Israel & 7.5 & 7.5 & 7.3 & 7.7 & 7.9 & 7.8 & 7.5 & 7.4 & 7.6 \\
\hline Italy & 6.1 & 6.0 & 6.0 & 5.9 & 6.0 & 6.1 & 6.1 & 6.2 & 6.2 \\
\hline Korea & 4.1 & 4.1 & 4.3 & 4.1 & 4.2 & 3.8 & 4.2 & 4.3 & 4.3 \\
\hline Latvia & 6.7 & 6.8 & 7.2 & 7.4 & 7.6 & 7.7 & 8.1 & 8.0 & 8.3 \\
\hline Lithuania & 7.7 & 7.8 & 7.5 & 7.5 & 7.5 & 7.7 & 7.8 & 7.8 & 7.8 \\
\hline Luxembourg & 6.4 & 6.6 & 7.1 & 7.3 & 7.4 & 6.6 & 6.4 & 6.2 & 6.3 \\
\hline Mexico & 3.8 & 3.7 & 3.7 & 3.4 & 3.8 & 3.8 & 3.9 & 3.7 & 3.9 \\
\hline Netherlands & 6.7 & 6.4 & 6.4 & 6.4 & 6.4 & 6.5 & 6.8 & 6.8 & 6.8 \\
\hline New Zealand & 9.3 & 9.4 & 9.6 & 9.3 & 9.5 & 9.6 & 9.5 & 9.7 & 9.8 \\
\hline Norway & 7.8 & 7.5 & 7.5 & 7.6 & 7.7 & 8.2 & 8.6 & 8.6 & 8.5 \\
\hline Poland & 7.6 & 7.8 & 7.1 & 7.0 & 7.1 & 7.0 & 7.2 & 7.8 & 8.1 \\
\hline Portugal & 7.5 & 8.1 & 8.3 & 8.1 & 8.5 & 8.5 & 8.5 & 8.6 & 8.9 \\
\hline Slovak Republic & 6.2 & 6.7 & 6.0 & 6.3 & 6.6 & 6.8 & 6.7 & 7.0 & 7.0 \\
\hline Slovenia & 8.1 & 8.1 & 8.0 & 8.4 & 8.4 & 8.3 & 8.2 & 8.1 & 8.2 \\
\hline
\end{tabular}




\begin{tabular}{|c|c|c|c|c|c|c|c|c|c|}
\hline Spain & 5.3 & 5.2 & 5.4 & 5.9 & 6.2 & 6.4 & 6.4 & 6.4 & 6.6 \\
\hline Sweden & 9.2 & 9.0 & 8.9 & 9.0 & 9.0 & 9.0 & 9.2 & 9.3 & 9.3 \\
\hline Switzerland & 3.4 & 3.5 & 3.5 & 3.5 & 3.5 & 3.4 & 3.4 & 3.4 & 3.3 \\
\hline Turkey & 5.4 & 5.6 & 5.2 & 5.6 & 5.0 & 5.2 & 5.0 & 5.0 & 4.8 \\
\hline United Kingdom & 6.0 & 6.8 & 6.7 & 6.7 & 6.7 & 6.8 & 6.8 & 6.9 & 7.0 \\
\hline Sample mean & 6.66 & 6.74 & 6.78 & 6.80 & 6.89 & 6.89 & 6.96 & 7.02 & 7.06 \\
\hline Ukraine & 7.97 & 9.88 & 9.85 & 8.82 & 8.87 & 9.02 & 5.88 & 5.95 & 6.01 \\
\hline
\end{tabular}

Source: own elaboration of OECD and World Bank data.

As Table 5 shows that - in Ukraine - the VAT-to-GDP ratio in 2015 was higher than in other countries, while in 2016-2018, it was lower than the mean value in the sample. This can be explained by the fact that the Ukrainian state adopted a more harmonized procedure for refunding VAT and cut delays in VAT refunds. The nominal VAT rate in Ukraine is quite moderate, lower than in Germany, Turkey, and Switzerland. In almost all of these countries, the effective VAT rate is lower than the nominal, which can be explained by the fact that reduced VAT rates are applied to certain groups of commodities.

Noteworthy, the above countries experience no significant fluctuations in the VAT-to-GDP ratio, which signifies a relatively stable level of taxation in these countries. An increase in the VAT-to-GDP ratio in the Czech Republic, Estonia, and Latvia stems from the gradual increase in the basic VAT rate by 1-2 percentage points each time.

At this point, we should emphasize that among other taxes in Ukraine, VAT is the one most harmonized with EU legislation. If we compare the current VAT rate in Ukraine with that of other countries, we notice that it generally corresponds to international norms, as VAT-rates in EU and OECD countries tend to be stable (Table 6); more tax revenue is expected from administrative and anti-fraud measures (Tax Policy Reforms, 2019; Taxation trends in EU, 2019).

Therefore, debates about VAT now mostly focus on its administration and collection. However, we should remember that all EU countries, except for Denmark, apply reduced VAT rates to some pharmaceutical products, food necessities, public transportation fees, and periodicals. In Ukraine, a reduced VAT rate (7\%) is applied only to pharmaceutical products and medical equipment. This rate does not qualify as a reduction of tax burden, since medical drugs and equipment were VAT-free before it was introduced. 
Table 6. VAT rates in OECD countries and Ukraine in 2010-2018

\begin{tabular}{|c|c|c|c|c|c|c|c|c|c|c|}
\hline \multirow{2}{*}{ Country } & 2010 & 2011 & 2012 & 2013 & 2014 & 2015 & 2016 & 2017 & 2018 & \multirow{2}{*}{ Reduced Rate } \\
\hline & \multicolumn{9}{|c|}{ Standard Rate } & \\
\hline Austria & 10 & 10 & 10 & 10 & 10 & 10 & 10 & 10 & 10 & 0 \\
\hline Belgium & 20 & 20 & 20 & 20 & 20 & 20 & 20 & 20 & 20 & $10 / 13$ \\
\hline Canada & 5 & 5 & 5 & 5 & 5 & 5 & 5 & 5 & 5 & 0 \\
\hline Chile & 19 & 19 & 19 & 19 & 19 & 19 & 19 & 19 & 19 & - \\
\hline $\begin{array}{l}\text { the Czech } \\
\text { Republic }\end{array}$ & 20 & 20 & 20 & 20 & 21 & 21 & 21 & 21 & 21 & $10 / 15$ \\
\hline Denmark & 25 & 25 & 25 & 25 & 25 & 25 & 25 & 25 & 25 & 0 \\
\hline Estonia & 20 & 20 & 20 & 20 & 20 & 20 & 20 & 20 & 20 & $0 / 9$ \\
\hline Finland & 22 & 23 & 23 & 24 & 24 & 24 & 24 & 24 & 24 & $0 / 10 / 14$ \\
\hline France & 19.6 & 19.6 & 19.6 & 19.6 & 20 & 20 & 20 & 20 & 20 & $2.1 / 5.5 / 10$ \\
\hline Germany & 19 & 19 & 19 & 19 & 19 & 19 & 19 & 19 & 19 & 7 \\
\hline Greece & 19 & 23 & 23 & 23 & 23 & 23 & 23 & 24 & 24 & $6 / 13$ \\
\hline Hungary & 25 & 25 & 27 & 27 & 27 & 27 & 27 & 27 & 27 & $5 / 18$ \\
\hline Iceland & 25.5 & 25.5 & 25.5 & 25.5 & 25.5 & 24 & 24 & 24 & 24 & $0 / 11$ \\
\hline Ireland & 21 & 21 & 23 & 23 & 23 & 23 & 23 & 23 & 23 & 0/4.8/9.0/13.5 \\
\hline Israel & 16 & 16 & 16 & 17 & 18 & 18 & 17 & 17 & 17 & 0 \\
\hline Italy & 20 & 20 & 21 & 21 & 22 & 22 & 22 & 22 & 22 & $4 / 5 / 10$ \\
\hline Korea & 10 & 10 & 10 & 10 & 10 & 10 & 10 & 10 & 10 & 0 \\
\hline Latvia & 21 & 22 & 22 & 21 & 21 & 21 & 21 & 21 & 21 & $5 / 12$ \\
\hline Lithuania & 21 & 21 & 21 & 21 & 21 & 21 & 21 & 21 & 21 & $5 / 9$ \\
\hline Luxembourg & 15 & 15 & 15 & 15 & 15 & 17 & 17 & 17 & 17 & $3 / 8 / 14$ \\
\hline Mexico & 16 & 16 & 16 & 16 & 16 & 16 & 16 & 16 & 16 & 0 \\
\hline the Netherlands & 19 & 19 & 19 & 21 & 21 & 21 & 21 & 21 & 21 & 6 \\
\hline New Zealand & 12.5 & 15 & 15 & 15 & 15 & 15 & 15 & 15 & 15 & 0 \\
\hline Norway & 25 & 25 & 25 & 25 & 25 & 25 & 25 & 25 & 25 & $2 / 12 / 15$ \\
\hline Poland & 22 & 23 & 23 & 23 & 23 & 23 & 23 & 23 & 23 & $5 / 8$ \\
\hline Portugal & 20 & 23 & 23 & 23 & 23 & 23 & 23 & 23 & 23 & $6 / 13$ \\
\hline
\end{tabular}




\begin{tabular}{|c|c|c|c|c|c|c|c|c|c|c|}
\hline $\begin{array}{l}\text { the Slovak } \\
\text { Republic }\end{array}$ & 19 & 20 & 20 & 20 & 20 & 20 & 20 & 20 & 20 & 10 \\
\hline Slovenia & 20 & 20 & 20 & 20 & 22 & 22 & 22 & 22 & 22 & 9.5 \\
\hline Spain & 16 & 18 & 21 & 21 & 21 & 21 & 21 & 21 & 21 & $4 / 10$ \\
\hline Sweden & 25 & 25 & 25 & 25 & 25 & 25 & 25 & 25 & 25 & $0 / 6 / 12$ \\
\hline Switzerland & 7.6 & 8 & 8 & 8 & 8 & 8 & 8 & 8 & 7.7 & $0 / 6 / 12$ \\
\hline Turkey & 18 & 18 & 18 & 18 & 18 & 18 & 18 & 18 & 18 & $1 / 8$ \\
\hline $\begin{array}{l}\text { the United } \\
\text { Kingdom }\end{array}$ & 17.5 & 20 & 20 & 20 & 20 & 20 & 20 & 20 & 20 & $0 / 5$ \\
\hline Sample Mean & 18.51 & 19.06 & 19.31 & 19.40 & 19.56 & 19.58 & 19.55 & 19.58 & 19.57 & \\
\hline Ukraine & 20 & 20 & 20 & 20 & 20 & 20 & 20 & 20 & 20 & $0 / 7$ \\
\hline
\end{tabular}

Source: own elaboration of OECD data.

Changes in approaches to VAT administration in Ukraine raise a number of questions. Overall, however, the introduction of the electronic VAT administration system in 2015 helped the authorities to minimize risks of fictitious tax credits and simplify the process of VAT declaration and payment. On the other hand, the majority of firms offering their customers deferred payment terms faced difficulties when trying to register their tax invoices in the electronic system while shipping products. In order to register a tax invoice, it is necessary for them to have the corresponding sum of money on the taxpayer's account in the Treasury Service. For example, if a tax invoice for the sum of UAH 120,000, including VAT of UAH 20,000, needs to be registered, the taxpayer's electronic account must have a balance of UAH 20,000. This amount consists of the VAT amount in tax invoices registered by the company's suppliers, the VAT amount paid to import goods, the money transferred by the taxpayer, and the monthly average of the VAT amounts declared by the taxpayer in the last twelve fiscal months and discharged (or amortized/deferred). If the sum on the taxpayer's account is insufficient, the taxpayer has to transfer funds from their current bank account (however, funds cannot be withdrawn back from your taxpayer's account) to avoid paying a fine for delayed registration and losing a customer, because without the registered tax invoice, the customer loses their right to the tax credit. The purpose of the electronic system is to prevent VAT fraud and evasion due to fictitious tax credits, but this system also hampers the efficient operation of companies.

The introduction of the system in 2015-2016 did not help the government solve the problem of timely VAT refunds on exported goods. The situation improved only in 2017, when the register of companies claiming the VAT refund became publicly open. 
Before 2017, such registers were closed, which led to a high risk of corruption associated with 'line jumping.' When the registers became open, the transparency of the 'line jumping system' also improved as companies were now able to keep track of the process.

Another problem taxpayers faced in 2017 was that the system blocked the registration of tax invoices if it detected a high level of risk of fictitious transactions. Sometimes this mechanism created absurd situations. For instance, tax invoices of a manufacturing enterprise were blocked because the system did not have the information that this production was previously bought by the same enterprise.

Confusion and uproar among taxpayers led to a large number of lawsuits filed against the State Tax Service. As a result, the Ministry of Finance had to revise the criteria for blocking tax invoices. Thus, the improvement of the electronic system remains a work in progress.

\section{Empirical Findings}

The reform of the mid-1990s - which involved the lowering of VAT rate and the elimination of contributions to special budgetary funds - generally brought positive effects. These measures allowed the government to stabilize the decline in GDP growth rate and ensure a level of macro-economic stability. In the early 2000s, the country finally achieved a position of economic growth. Undoubtedly, tax burden reduction made a substantial contribution to this success, even though it was not the sole factor.

However, it is much harder to evaluate the impact of the transition from progressive personal income taxation to proportional taxation. The rationale behind this transition was the need to deal with the problem of unreported income and tax evasion, thus to encourage businesses to move from the shadow economy to the formal economy. Proponents of this reform argued that transition would boost tax revenues even with lower tax rates. Nevertheless, as practice revealed, no breakthrough occurred in this respect as the problem of tax evasion remained unsolved and even worsened. On the other hand, there also ensued no slump in tax revenues.

Over the following years after the change from progressive to proportional taxation in 2003, tax revenues grew considerably: from UAH 34800 billion to UAH 45900 billion in 2008. These were the years of economic boom in Ukraine in which - although we cannot deny the positive impact of the reduced tax burden - the crucial factor was the growth of GDP. Undoubtedly, reduced income tax rates stimulated consumption 
and thus enhanced economic growth. Unfortunately, not all income groups benefited the same from this reform, as the rich gained the most. Reduced tax rates could be expected to raise investment, which would signify the success of personal income tax reform. However, the reform did not bring about the expected investment boom, which is unlikely to happen in the near future. The reduction in the corporate income tax rate was primarily aimed at encouraging investment, at least according to the official version of the previous Ukrainian government. Officials insisted that the proposed tax incentives would result in an unprecedented inflow of investment which, however, did not happen.

Therefore, it can be concluded that the reform failed to bring the desired result or was perhaps doomed to failure from the onset. According to studies by EY, PwC, Deloitte, and the World Bank, the main factor in foreign investor decision-making is not corporate tax rate but the protection of their property rights, the rule of law, and the government efficiency. According to the Heritage Foundation, Ukraine's position remains stubbornly low in these indicators. As for the integral indicator, Ukraine ranks among the economically unfree countries (Index of Economic Freedom, 2019) such as Afghanistan, Sudan, Angola, Suriname, and Bolivia. Therefore, it is essential that changes in the sphere of taxation are accompanied by complementary institutional transformations. Otherwise, the benefits from reform will be enjoyed only by a small privileged circle of those who lobby for these changes in the first place, while the general level of public welfare will remain basically the same. The same ideas were discussed by Rudolph (2009), who proves that political trust should increase, not decrease when the political decision to reduce the taxes is made. Figure 2 illustrates the dynamics of the index of economic freedom and tax burden in Ukraine.

As the graph above shows, the position of Ukraine in the ranking of economic freedom leaves much to be desired. Even though its index grew from 40.6 to 51.9, it is still not enough for Ukraine to move into the next group in the ranking. As Figure 2 illustrates, after 2002, the index of tax burden grew considerably, which means that the tax reforms had a positive impact on tax climate in the country.

As previously noted, the index of economic freedom is one of the integral indicators characterizing a country's economic and institutional development. To evaluate the influence of tax reforms on economic freedom, we constructed two regressions with two dependent variables: the index of economic freedom (integral indicator) and the index of tax burden (a component of economic freedom). Tax burden - as the share of tax revenues in GDP - was used as an independent variable. The sample covers the period from 2008 to 2018. The results of our calculations are shown in Table 7. 
Figure 2. Changes in the level of the index of economic freedom and the index of tax burden for Ukraine in 1996-2018

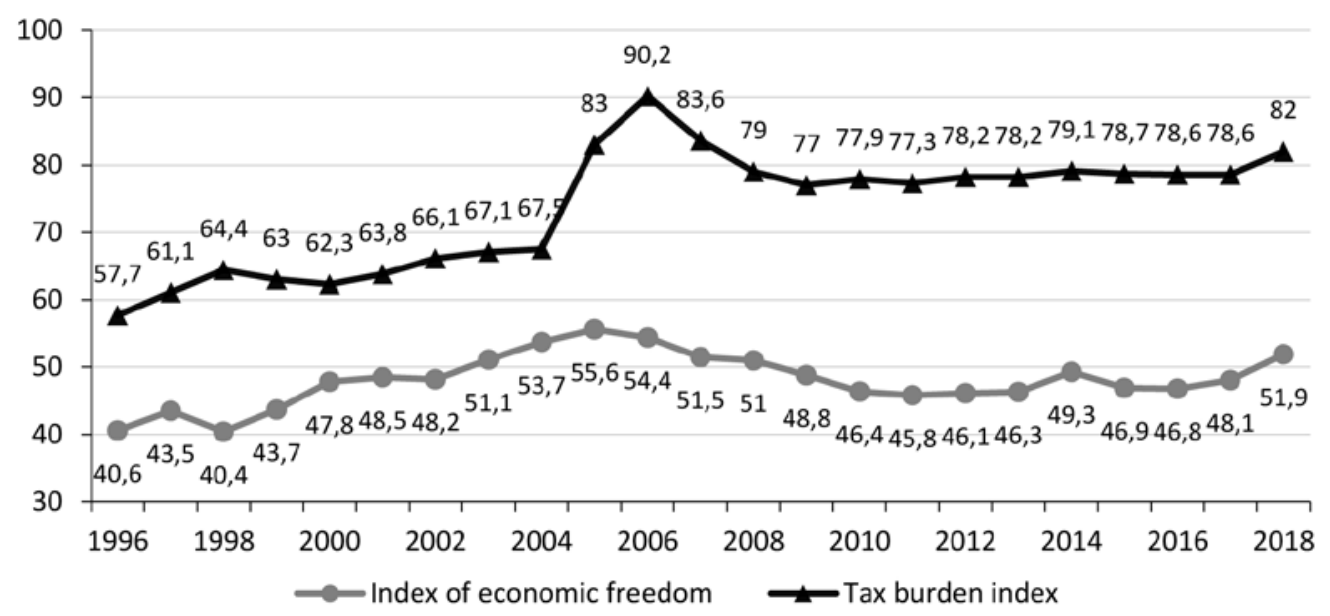

Source: own elaboration of Heritage Foundation data.

Table 7. Regression statistics results

\begin{tabular}{|l|c|c|}
\hline \multicolumn{2}{|c|}{ Linear Model } \\
\hline & \multicolumn{2}{|c|}{ Dependent Variable } \\
\hline & $\begin{array}{c}\text { IEF index of economic } \\
\text { freedom) }\end{array}$ & FF (Fiscal Freedom) \\
\hline & -0.006 & $0.231^{\star *}$ \\
\hline Observations & $(0.283)$ & $(0.432)$ \\
\hline$R^{2}$ & 20 & 20 \\
\hline Adjusted $R^{2}$ & 0.00002 & 0.613 \\
\hline Residual Std. Error (df=9) & 0.056 & 0.592 \\
\hline F Statistic (df=1;9) & 3.258 & 0.4322 \\
\hline
\end{tabular}

Note: ${ }^{*} \mathrm{p}<0.1 ;{ }^{* *} \mathrm{p}<0.05 ;{ }^{* *} \mathrm{p}<0.01$

Source: own elaboration.

The F-statistic and p-value show the significance of the second regression. The coefficient of determination (adjusted to consider the sample size) for the dependence of the index of economic freedom/tax-to-GDP ratio is 0.056 ; for the dependence of the index 
of fiscal freedom (index of tax burden)/tax-to-GDP ratio is 0.592. In 2008-2018, the tax reforms sought to reduce the tax base determined as more than $40 \%$ of the dynamics of the country's economic freedom index.

Table 7 reveals that the coefficient of determination for the first regression dependence is very low. It means that there is no correlation between the variables under study. Therefore, we must reject the first hypothesis that the reduced tax burden in Ukraine positively impacts the level of economic freedom of Ukraine. This is due to the fact that tax cuts are not accompanied by the necessary institutional reforms in the country. According to the World Bank and the Heritage Fund, Ukraine has very high corruption risks, low accountability, and low protection of property rights. Therefore, tax cuts alone do not contribute to the growth of the index of economic freedom, despite the fact that fiscal freedom is part of this index. Three main facts described in part 5.1 testify to the fact that institutional reforms in the field of taxation are very slow. The first fact is the frequent changes in tax legislation. These are not just small changes in tax rates but changes in the methodology of tax calculation and administration. This destabilizes the institutional environment and makes it difficult for taxpayers to plan business activities. The second fact is related to the late streamlining of tax legislation. The Tax Code was adopted twenty years after the establishment of Ukraine as an independent state. Before the adoption of the Tax Code, tax collection was regulated not only by laws but also by many secondary pieces of legislation such as orders, letters, or decrees. This created uncertainty in relations between the state and taxpayers, which led to frequent conflicts. The third fact is that, before 2003, there was no law in Ukraine that would regulate the administration of taxes. The procedure of tax inspections, their frequency, and the imposition of fines were unregulated.

As we learn from Table 7, the coefficient of determination for the second regression dependence exceeds 0.5 , which is sufficient for panel regression. The elasticity coefficient indicates that a $1 \%$ decrease in tax burden leads to an improvement in the fiscal freedom indicator by $0.23 \%$. Therefore, this confirms the second hypothesis that the reduced tax burden had a positive effect on the level of fiscal freedom of Ukraine.

We should note that although in the given period the reduction of tax burden was one of the priorities of Ukraine's fiscal policy - and it did not have a positive impact on the level of economic freedom - Ukraine remained in the group of economically unfree countries, which means that the impact of the reform was smaller than expected. The impact of the tax-to-GDP ratio on fiscal freedom is positive. This difference in the impact of tax burden on the economic freedom index and the fiscal freedom index can be explained by the low efficiency of institutional reforms. In fact, Ukraine has a situation 
when the legislative basis of taxation is in line with international best practices, but at the same time, it lacks a mechanism for tax law execution.

\section{Conclusion}

The results of our study show that Ukraine went through four main stages of tax reform. At the initial stage (1991-1997), the key priority was to establish a tax system that would ensure stable budget revenues. Although at this stage, the fiscal function prevailed, some steps were taken to reduce tax burden. In the second stage (1997-2000), tax regulations were developed, and the main taxes were harmonized with international norms. At the third stage (2000-2010), the government attempted to balance the fiscal and regulatory functions of taxes. The fourth stage, starting in 2011, has involved the codification of tax legislation, the simplification of the tax system, and its further harmonization with EU legislation. The search for ways to reduce tax burden continues.

In Ukraine, the resulting tax system is characterized by a moderate tax burden in comparison to OECD countries. The tax burden of corporate tax in Ukraine is lower than in the OECD countries. The initiators of tax law in Ukraine lacked a clear strategy and tactics, which led to some unpredictable results. Furthermore, institutional changes in Ukraine have always tended to recede into the background while priority was given to the reduction of tax burden and the struggle against tax fraud and tax evasion. As a result, Ukraine has remained in the group of economically unfree countries due to its unbalanced reforms and insufficient institutional and structural changes. Therefore, these factors have prevented Ukrainian policymakers from ensuring the desired effect of tax burden reduction.

Future research should include a more in-depth comparative analysis of tax reform in Ukraine by focusing on key taxes.

\section{References}

Agrawal, D.R. and Foremny, D. (2018). Relocation of the Rich: Migration in Response to Top Tax Rate Changes from Spanish Reforms. Review of Economics and Statistics.

https://www.mitpressjournals.org/doi/abs/10.1162/rest_a_00764.

Akcigit, U., Baslandze, S. and Stantcheva, S. (2016). Taxation and the International Mobility of Inventors. American Economic Review, 106(10), 2930-2981. https://doi.org/10.1257/aer.20150237. 
Barrios, S., Huizinga, H., Laeven, L. and Nicodème, G. (2012). International taxation and multinational firm location decisions. Journal of Public Economics, 96, 946-58. https://doi.org/10.1016/j.jpubeco.2012.06.004.

Barro, R. and Furman, J. (2018). The Macroeconomic Effects of the 2017 Tax Reform, Brookings Papers on Economic Activity. https://www.brookings.edu/wp-content/uploads/2018/03/4_barrofurman. pdf, https://doi.org/10.1353/eca.2018.0003.

Barro, R.J. et al. (2017). How Tax Reform Will Lift the Economy. The Wall Street Journal. https:/ www.wsj.com/articles/how-tax-reform-will-lift-the-economy-1511729894, https://doi.org/10.1353/ eca.2018.0003.

Berggren, N. (2003). The Benefits of Economic Freedom: A Survey. Independent Review, 8(2), 193-211.

Borzenkova, O. (2015). Podatkova reforma v Ukraini: mizhnarodnyi dosvid ta ohliad perspektyvnykh zmin [Tax reform in Ukraine: international experience and a review of promising changes]. Biznes Inform, 10, 354-358 (in Ukr.).

Carlsson, F. and S. Lundström (2002). Economic Freedom and Growth: Decomposing the Effects. Public Choice, 112(3-4), 335-44. https://doi.org/10.1023/A:1019968525415.

Deloitte, International Tax and Business Guide, Country Highlights. https:// www.dits.deloitte.com.

Doucouliagos, C. and Ulubasoglu, M.A. (2006). Economic Freedom and Economic Growth: Does Specification Make a Difference? European Journal of Political Economy, 22(1), 60-81. https://doi.org/10.1016/j.ejpoleco.2005.06.003.

Egger, P. and Winner, H. (2004). Economic Freedom and Taxation: Is There a Trade-off in the Locational Competition between Countries? Public Choice, 118(3/4), 271-288. https://doi.org/10.1023/B:PUCH.0000019904.30629.33.

Fedosov, V. and Paientko, T. (2017). Ukrainian Government Bureaucracy: Benefits and Costs for the Society. Business and Management Studies, 3(2), 8-19. https://doi.org/10.11114/bms.v3i2.2358.

Furman, J. (2016). Dynamic Analysis, Welfare, and Implications for Tax Reform. Remarks at the National Bureau of Economic Research Tax Policy and the Economy Conference. Washington.

Gale, W.G. and Samwick, A.A. (2014). Effects of Income Tax Changes on Economic Growth. Economic Studies at Brookings, 1, 1-15. https://doi.org/10.2139/ssrn.2494468.

Gehring, K. (2012). Benefit or Burden? Unraveling the Effect of Economic Freedom on Subjective Well-Being. University of Heidelberg, Department of Economics Working Paper, 531.

Guvenen, F., Mataloni, R.J., Jr., Rassier, D.J., and Ruhl, K.J. (2017). Offshore Profit Shifting and Domestic Productivity Measurement. NBER Working Paper No. 23324. Cambridge, MA: National Bureau of Economic Research. https://doi.org/10.3386/w23324.

Hrechko, A.V. (2014). Perspektyvy reformuvannia podatkovoi systemy Ukrainy v umovakh yevrointehratsii [Prospects for reforming Ukraine's tax system in the context of European integration]. Problemy ekonomiky, 3, 60-70 (in Ukr.).

Jametti, M., Redonda, A. and Sen, A. (2013). The power to pass on taxes: a test for tax shifting based on observables. CESifo, Working Paper no. 4265.

Joseph, A., Biggs, A., Brill, A., and Viard, A. (2015) Tax and spending reform for fiscal stability and economic growth. AEI Economic Perspectives, https://papers.ssrn.com/sol3/papers.cfm?abstract_id=2710963.

Iliashenko, V.A. (2013). Rozvytok podatkovoi systemy Ukrainy v umovakh yevrointehratsii [Development of the tax system of Ukraine in the conditions of European integration]. Derzhava ta rehiony. Seriia: Ekonomika ta pidpryiemnytstvo, 2(71), 15-20 (in Ukr.).

Index of economic freedom. Heritage foundation. Available at: https://www.heritage.org/index. 
McBride, W. (2012). What Is the Evidence on Taxes and Growth? Special Report No. 207. Washington, D.C: The Tax Foundation.

Melnyk, V.M. and Koshuk, T.V. (2014). Podatkovi reformy v umovakh hostroho defitsytu fiskalnykh resursiv: dosvid krain YeS ta ukrainski realii [Tax reforms in the context of acute shortage of fiscal resources: EU experience and Ukrainian realities]. Ekonomika Ukrainy, 6, 37-56 (in Ukr.).

Nohinova, N. (2014). Neobkhidnist reformuvannia podatkovoi polityky Ukrainy v umovakh yevrointehratsii [Need to reform Ukraine's tax policy in the context of European integration]. Naukovi zapysky Natsionalnoho universytetu «Ostrozka akademiia». Seriia «Ekonomika», 25, 141-145 (in Ukr.).

OECD, https://stats.oecd.org/viewhtml.aspx? datasetcode=REV\&lang.

Oparin, V. and Paientko, T. (2017). Ideolohiya, pragmatyka ta resultatyvnist podatkovoho reformuvania v Ukraini [Ideology, pragmatics and effectiveness of tax reform in Ukraine]. Problemy economiky, 4, 138-147 (in Ukr.).

Paientko, T. and Proskura, K. (2016). Corporate income taxation - selected problems and decisions. The case of Ukraine. Zeszyty Teoretyczne Rachunkowości, 135-142.

Rode, M. and Coll, S. (2012). Economic Freedom and Growth. Which Policies Matter the Most? Constitutional Political Economy, 23(2), 95-133. https://doi.org/10.1007/s10602-011-9116-x.

Rudolph, T.J. (2009). Political Trust, Ideology, and Public Support for Tax Cuts. Public Opinion Quarterly, 73(1), 144-158. https://doi.org/10.1093/poq/nfp012.

Schmidheiny, K., and Slotwinski, M. (2018). Tax-Induced Mobility: Evidence from a Foreigners' Tax Scheme in Switzerland. Journal of Public Economics, 167, 293-324.

Shadow Economy in Ukraine, http://www.me.gov.ua/Documents/List?lang=uk-UA\&id=e384c5a7-6533-4ab6-b56f-50e5243eb15a\&tag=TendentsiiTinovoiEkonomiki. https://doi.org/10.1016/j. jpubeco.2018.04.002.

Tanzi, V. (1997). Macroeconomics Dimensions of Public Finance. Routledge.

Tax Policy Reforms 2019, OECD and selected partner economies, https://www.oecd.org/tax/tax-policy/Tax-Policy-Reforms-2019-brochure.pdf.

Taxation trends in EU, https:/ec.europa.eu/taxation_customs/ sites/taxation/files/taxation_trends_ report_2019.pdf.

Turianskyi, Yu. (2014). Podatkova reforma u systemi zakhodiv antykryzovoho rehuliuvannia ekonomiky Ukrainy [Tax reform in the system of measures of anti-crisis regulation of the economy of Ukraine]. Naukovyi visnyk NLTU Ukrainy, 24.5, 315-320 (in Ukr.).

World Bank statistic, https://data.worldbank.org/indicator/ GC.TAX.YPKG.RV.ZS?view=chart. 